\title{
Religious Worldview of Knut Hamsun
}

\author{
Maria Matyushova \\ Peoples' Friendship University of Russia \\ 6 Miklukho-Maklaya \\ Moscow, Russia \\ E-mail:maria_matushova@mail.ru
}

\begin{abstract}
The paper considers the religious worldview of Norwegian writer Knut Hamsun, (Knut Pedersen) (1859-1952). He was Nobel Prize Laureate in Literature for 1920. He became famous after the publication of the novel Hunger, which appeared in 1890. The author, based on the early works of Knut Hamsun, such as Pan, Victoria, characterizes Hamsun's religious views as aesthetic pantheism.
\end{abstract}

Keywords-religious worldview; pantheism; aesthetic pantheism

\section{INTRODUCTION}

Hamsun's name is associated with the emergence of a new protest neoromantic literature in the North, a literature of inner motivation that connects realism, psychology and symbolism. The novel The Hunger is a kind of journey into the world of the soul, an artistic, psychological, almost uninterrupted analysis of the spiritual state of the hero of the novel. This is a confession of a young and ambitious man which have literary talent, but completely devoid of any means of subsistence, suffering the soul and body, appealing to God with questions about justice. Critics considered Hamsun's novel as the best of all his novels, calling Hamsun the predecessor of Beckett, Kafka, and Joyce, Virginia Woolf. Hamsun himself believed that Dostoyevsky had a strong influence on his creativity.

In Hamsun's work we will not find a harmonious philosophical system of his views on religion, the statements on this topic are scattered about his novels and stories, but from these judgments we can weave a single thread, form a single concept of the world, the relationship of the world and God, God and human being.

In general, Hamsun's philosophical worldview was formed under the influence of German Romanticism, especially the philosophy of Schelling, pessimism and subjectivity of A. Schopenhauer, in particular, under influence of his idea that man is only a blind puppet, subject to the cosmic principle - the World Will. The teachings of Edward Hartmann on the unconscious also predetermine to him. In addition, a great influence on him had the philosophy of F. Nietzsche, his reflections on the will to power and the idea of the Superman.

\section{THE THEME OF THE “INNOCENT SUFFERER”}

The central theme in the novel of the Hunger is the theme of creativity and suffering of the artist, the theme of "the innocent sufferer". Only in this novel of Hamsun we see the concept of a personal God. The hero of Hamsun decries and rejects the Christian God, because he cannot understand the "monstrous injustice" of God, cannot understand why "finger of God" chose him. Analyzing your own destiny, he is looking for the cause of his suffering: why he was chosen by God for suffering, "chosen by the willful providence of God for his exercises", then in his mind arises another thought - maybe God test his faith. He recalls his school years, when he studied the Bible, recalls the commandment, which says that one, does not need to worry about the future, as birds and animals do not care about it. These memories and his present hard condition not only do not reconcile him with God, but on the contrary, cause a protest.

This eternal question of the «innocent sufferer» reflected in the Babylonian poem I Want to Glorify the Master of Wisdom and in the biblical Book of Job is especially powerful express in novel of Hamsun: "The Lord stuck His finger in the net of my nerves gently--yea, verily, in desultory fashion--and brought slight disorder among the threads. And then the Lord withdrew His finger, and there were fibres and delicate root-like filaments adhering to the finger, and they were the nerve-threads of the filaments. And there was a gaping hole after the finger, which was God's finger, and a wound in my brain in the track of His finger. But when God had touched me with His finger, He let me be, and touched me no more, and let no evil befall me; but let me depart in peace and let me depart with the gaping hole. And no evil hath befallen me from the God who is the Lord God of all Eternity" [1].

Therefore, to a large extent the share of responsibility for the sufferings of the young writer lies with Providence and if you are noted by "finger of God", then you will suffer and suffer. The Knowledge of this fact leads to the protest against God, he doesn't want to obey him; he doesn't not want to take it for granted, and unlike Job, falls into almost wild blasphemy. In his mind, God is identified with the Phoenician cruel Baal, and with the god of Egypt - Apis: "I tell you, I would scoff you on the day of doom, and curse the teeth out of my mouth for the sake of your Deity's boundless miserableness! I tell you from this hour I renounce all thy 
works and all thy pomps! I will execrate my thought if it dwell on you again, and tear out my lips if they ever utter your name! I tell you, if you exist, my last word in life or in death - I bid you farewell, for all time and eternity - I bid you farewell with heart and reins. I bid you the last irrevocable farewell, and I am silent, and turn my back on you and go my way.... Quiet" [2].

Thus, the Christian idea that suffering cleanses a person and thereby brings him closer to God, for according to the Bible (as says friend Job's Alizaph), “... man is born to suffering like sparks to rush upward" is not accepted by the hero of the novel, since suffering, on the contrary, remove us from God, and harden our heart [3]. No matter how righteous you are, no matter if your conscience is clean, (and in the novel there are plenty of examples of this young writer's pure conscience), you will be suffer. In this sense, unlike the book of Job, there is no theodicy in the novel, if we proceed from the definition of I. Kant, who wrote: “... of course, usually protection of the highest wisdom of the creator from the claim that the mind makes to her, proceeding from the fact that not all in the world it is expedient" [4].

Later, Hamsun expressed his position in the poem Sitting on an Overturned Boat in the first collection of poems in 1904 Wild Chorus, which included the old Poems of Passion (another version of the Russian name - Feverish Poems), and new poems.

You say that God is all good...

But why then, as an enemy,

Was he cruel when he created me?

You say, God is omniscient...

But then He could know,

What was always wrong to me!

He gave me a heart ... And on it

He painfully beats His whip,

While the last breath is interrupted...

You say: - there is a God! [5].

In the novel there is a rather strange answer - all the sufferings of the hero are explained by the jealousy of God to the creative power of the hero (the invention of the word 'Kuboa').

It is interesting that Alexei Kruchenykh in his "manifesto zaumi" is referring to Hamsun's experiment. "Zaum ('educanto') is the shortest art, both in the length of the path from perception to reproduction, and in its form, for example: Kuboah (Hamsun), Ho-bo-ro, and others" [6].

Kruchenykh also recalls the "misty beauty Illayali", a word that, in Kruchenykh's opinion, creates an indefinable image. But it is even more surprising that when the year of Hamsun was opened in Norway in February 2009, the exhibition that took place in the National Library in Oslo was establish on the first works of Hamsun, and it was called "Kuboaa".
At the same time, when the inspiration is suddenly visits the hero, and the novel has a classic description of this peak of the artistic process, the hero kneels and thanks God, because he understands that this is a miracle, this gift is sent down to him from some unforeknowable forces: "It was as if a vein had burst in me; one word follows another, and they fit themselves together harmoniously with telling effect. Scene piles on scene, actions and speeches bubble up in my brain, and a wonderful sense of pleasure empowers me. I write as one possessed, and fill page after page, without a moment's pause.

Thoughts come so swiftly to me and continue to flow so richly that I miss a number of telling bits, that I cannot set down quickly enough, although I work with all my might. They continue to invade me; I am full of my subject, and every word I write is inspired" [7].

Inspiration is not caused either by persistent labor, by a long sitting at the desk, and by writing a certain number of pages, for "no one knows the day or hour when the spirit descends upon a man" [8]. It is directly connected with a rich imagination, exaltation, ecstasy, almost, delirium, and hallucinatory visions. At this moment, the world is phenomenal, and it means there are not a clear distinction between past and present, (moments of time are interchangeable), but between sleep and wakefulness. Schopenhauer's assertion that "the world is my representation" can accurately determine this state of the hero of Hamsun, especially in the novel Hunger. Reality, the world of actual phenomena ceases to exist completely for the hero of the novel, and the fictional world is even more real. At the same time, the thought becomes unusually clear, everything is easily resolved, the hero feels himself a medium of the will of God: "There is the Lord! There the Lord!" - he exclaims.

\section{III. "AESTHETIC PANTHEISM"}

In his later novels, Hamsun proposes a different understanding of God, close to the pantheistic tradition. His works, especially such novels as Pan, Mysteries, proclaim the domination of nature over culture and reason, nature as an objective reality that surrounds man, and the nature of man, governed by unconscious impulses and instincts. The pantheistic vision of the world of Hamsun is colored by an exalted deep sense of admiration of nature.

"Hail, men and beasts and birds, to the lonely night in the woods, in the woods! Hail to the darkness and God's murmuring between the trees, to the sweet, simple melody of silence in my ears, to green leaves and yellow! Hail to the life-sound I hear; a snout against the grass, a dog sniffing over the ground! A wild hail to the wildcat lying crouched, sighting and ready to spring on a sparrow in the dark, in the dark! Hail to the merciful silence upon earth, to the stars and the half-moon; ay, to them and to it! ..." [8].

This ecstasy before the private manifestations of the beautiful in nature and at the same time before the manifestation of the beautiful in the one being of God we find both in Schelling and in Hölderlin and Schleiermacher and, of course, in poetry of Blake with his famous poetic 
lines: "In one instant to see Eternity, Huge world - in a grain of sand, In one handful - infinity, And the sky - in a cup of flower".

In a letter to Eric Scrum (1888) Hamsun says: “... I fell in love with the light. I assure you this was a real sensual love, carnal. A lot of light, sunlight, daylight, huge lamps, terrible flame, devilish light around me and everywhere ..." And earlier: "The blood tells me that I am in a spiritual connection with the whole universe; with it's the elements" [9].

Later, the Russian poet - "sunshine", the translator of Hamsun, K. Balmont will write that the main symbol of his works is the statement "in himself and the world of solar energy, the energy behind which there is divine love". There are memories by K. Balmont when he was visiting Hamsun. Hamsun told him about his trip to America, and Balmont compares behavior of Hamsun with the Bengal tiger, which ran around the room, talking about the expanses of the prairie.

The mystical unity of man and nature, almost their identification, is so strong that the rhythm along which nature lives - spring, summer, autumn, winter, is projected on to human relations, people's lives, and love. So, the emergence of love is associated with the spring, when, after months of sleep, nature revives and awakens, life returns: "The spring had reached me too, maybe, and my blood beat at times as if it were footsteps" [10].

The peak of love, very short, falls on the summer; in autumn, along with fogs and rains, nature and love fade away, and, finally, in winter, everything stops.

The nature for Hamsun is more than just a place where you can go and then come back, it's not just solitude. In full, it replaces human society, in which life, together with its rules and conventions, is artificial and insincere. It is no coincidence that all the heroes of Hamsun's early novels are outsiders, wanderers, vagabonds, "unrequited", "superfluous" in society, as if outside the society. This is a young writer, the hero of novel Hunger, Lieutenant Glan in Pan, Nagel in Mysteries.

In his last novel The Circle Has Closed Hamsun also seems to return to the beginning of his creativity: author depict his protagonist as a tramp. Abel somewhat resembles the hippies of the 1960s: he also lived in Kentucky, and, returning to Norway, he denies any social norms, requirements that contributed to his inclusion in social life. All attempts by these heroes to somehow establish relations with society, often through love are finish complete collapse. They are not created for society or for love, happiness is not their destiny. Denying civilization, they feel happy when they are alone with the forest, with the ocean: "Among the majestic peace surrounding me, I am the only adult man, a wanderer, becoming more, more importantly, closer to God" [11].

There is no true freedom in society, it is a mirage, and nature is the realm of freedom, a source of happiness and consolation, even more: society destroys human relations; a person loses himself in society. At the same time, the relationships that people have in nature are not accompanied by conflicts; they arise only when the personality come into contact with society. Nature evokes in the hearts of heroes, and especially in the heart of Glan, the feeling of God's grace, Love for all living beings: «Blessed be life and earth and sky, blessed be my enemies; in this hour I will be gracious to my bitterest enemy, and bind the latchet of his shoe... [12].

Pan is traditionally interpreted by critics as a neoromantic novel. Perhaps in the spirit of Romanticism, the content of the novel can be explained as a conflict between nature and culture, since the whole novel is a hymn to Nature. The very title of the novel guides the reader to a certain understanding - an appeal to Greek mythology, to the image of Pan, to the spirit of forests. At the same time, the image of Pan does not occupy such an important place in Hamsun's thinking, as, for example, the image of Dionysus in creativity Nietzsche. However, these images are really similar in some ways, and perhaps Hamsun, in order not to go by the way of Nietzsche, used a different name to express the same phenomenon. Toure Hamsun in his book Knut Hamsun is My Father, writes that Glans image was most likely inspired by the Swedish writer Strindberg: "He calls himself a beast who aspires back to the forest", - says Hamsun, - "... according to Strindberg, a man withdrew from nature and thus lost the main prerequisites for an organic way of life" [13].

Pan, or "The Great God of Pan", as it is often called, was one of the most recognizable and revered pagan gods of the ancient world. Pan is a satyr that was depicted with a human body, but with horns, tail and hooves. His name comes from the old Greek word, which translates to paein, which means pasture. Other sources say that his name means everything, all-encompassing. In the Homeric hymn it is said that when Hermes brought the infant Pan to Olympus, all the gods were ecstatic, and they called him Pan, which means literally 'everything'.

The ancient philosophers of Alexandria believed that Pan represents the Natural Cosmos, and the word 'Pantheism' follows from this idea that all Nature is God and that God is all Nature: not just a manifestation of the material world, but as Anima Mundi, or World soul. It is interesting that in the center of Alexandria there was an artificially piled high hill, made in order to admire Alexandria, having risen on it. This hill was dedicated to Pan (Pansion) and it was surrounded a wonderful park.

The origin of Pan is shrouded in mystery. Some sources say that he was the son of the god Hermes, and his mother was a nymph, while others claimed that Pan was the son of Zeus, and he was nourished by the milk of Amalfeus, who was also the nurse of Zeus and Dionysus.

And although Pan is often referred to as one of the youngest gods, the myths say the opposite, for example, one of the myths says that Pan gave Artemis his hunting dogs. Also, none of the gods could find Demeter when she left Olympus, mourned and looked for her daughter Persephone, and it was Pan who found her whereabouts. 
According to the ancients, Pan was born in the pastoral Arcadia, the mountainous region of Greece, and it was there that his worship first arose. He became the patron god of the Arcadian shepherds, who prayed for the protection of their flocks from wolves and other predators. These shepherds hid their sheep in nearby caves after their consecration in honor of Pan, sacrificing lambs to him, and moreover they left cups of milk and honey.

Being a deity of nature, Pan is associated with forest groves, mountain slopes and gorges. He is the god of wild hunting and the patron of all animals.

Pan is also the personification of prophecy. It is believed that it was he who taught the god of Apollo the gift of prophecy. The ancients also believed that the cave associated with the oracle at Delphi was dedicated to Pan.

Often, Pan is described as the god of Eros, lust is the phallic god of carnal satisfaction. He has powerful magic that infects the unbridled sexual energy of those he chooses, this is the personification of the sexuality of man and animal, sexuality, which in ancient times was considered a vital sign of health and even divine blessing. This was the natural equation of man and animal as part of Nature.

Pan is also the god of war. He helped win the war against the Titans, as well as the war of Athens against the Persians.

Pan, like Dionysus, is the personification of the elements, the mysterious, mystical forces that exist in nature and affect for man. The title of the novel sets up a certain analogy of the way of life of the main character - Glan and Pan, even the figurine on the powder kiln is made in the form of Pan. Glan, like Pan wears a small bugle and his eyes have an «animal look», a source of magnetism and attractiveness, both for Edward and Eve and Henrietta, but this is also the source of Glance's suffering. This characteristic of Glan's glance indicates the presence of some kind of demonic beginning in Glan. Just like Pan, Glan experiences a period of intense melancholy. Glan, like Pan wanders through the forest and forest slopes, hunts a little, he is the "son of forest" and his "king". Often, he remains in the woods at night, lying on the ground, listening and looking into the night sky, waiting with the birds and animals for the dawn, rejoicing the sun. Glan is a part of this world, the nature in which he lives, he is mystically connected with it, feels all its changes. His feelings beat in rhythm with the Universe, in rhythm with silence and a gust of wind: "After an hour, my senses begin swinging in a certain rhythm. I am ringing in tune with the great stillness-ringing with it. I look at the half-moon; it stands in the sky like a white scale, and I have a feeling of love for it; I can feel myself blushing. "It is the moon!" I say softly and passionately; "it is the moon!" and my heart strikes toward it in a soft throbbing. So for some minutes. It is blowing a little; a stranger wind comes to me a mysterious current of air. What is it? I look round but see no one. The wind calls me, and my soul bows acknowledging the call; and I feel myself lifted into the air, pressed to an invisible breast; my eyes are dewed, I tremble - God is standing near, watching me. Again, several minutes pass. I turn my head round; the stranger wind is gone, and I see something like the back of a spirit wandering silently in through the woods..." [14].

God is present in the world, but at the same time God himself consists of this world, because God is both the blazing sunset sky and the raging sea; a storm and wind, a month and stars, dust on the road and a withered snag that causes the tears of Glan, a small blade of grass and large white flowers, leaves and ships on the sea. This is a certain cosmic force, in which there is a "brain of the Universe" and a hero, can sometimes observes how "work boils in it". Delight and reverence for the Beauty of this World pours out from Hamsun in prayerful thanksgiving words: "Thanks for the lonely night, for the hills, the rush of the darkness and the sea through my heart! Thanks for my life, for my breath, for the boon of being alive to-night; thanks from my heart for these! Hear, east and west, oh, hear. It is the eternal God. This silence murmuring in my ears is the blood of all Nature seething; it is God weaving through the world and me!" [15].

This is pantheism, of course, aesthetic pantheism, but it is Pantheism, because it is the "Pan" of the Universe, representing the entire Universe in its unity and orderliness, beauty and diversity: "God knows, I thought to myself, God knows why the sky is dressed in gold and mauve to-night, if there is not some festival going on up there in the world, some great feast with music from the stars, and boats gliding along river ways. It looks so!" [16].

And at the same time, this mystical God is the divine creative power inherent in Nature - this is the God of life and heart, who created this world by Love: "The Poet "Love is God's first word, the first thought that passed through his brain. When he said: Let there be light! Then love came. And all that he had made was very good, and he would have none of it unmade again. And love became the origin of the world and the ruler of the world. But all its ways are full of blossoms and blood, blossoms and blood" [17]. In this case Love is understood as an all-pervading, creative, forming all cosmic forces, originally present in God. In this case Hamsun poetically repeats the idea of Dante about the role of Love in the Divine Comedy:

"Some time had now from early morn elapsed,

And with those very stars the sun was rising

That in his escort were, when Love Divine

In the beginning moved those beauteous things;" [18].

Love as a cosmic force will be represented in the concepts of Giordano Bruno and Nicholas of Cusa, and later, the romantic Hölderlin in The Hymn of Beauty (1792) will also regard love as the active beginning of all things, as the divine principle manifested in the Universe the form of Harmony and the Beautiful.

Belief in the direct union of man and nature flows through the whole of the novel Hyperion: "My poor, rebellious, so many times wounded heart", - Hyperion exclaims at the very beginning of the novel, - "return to where you came from: into the arms of nature, unchanged, calm and beautiful" [19]. 
"Religion is a feeling and a taste for the infinite ...", wrote Schleiermacher, - "This is life in the infinite nature of the whole, in One and in everything, life that sees everything in God and God in everything ... It is the immediate perception of the being of everything generally finite in the infinite and through the infinite of all time in the eternal and through the eternal" [20].

\section{CONCLUSION}

The pantheism of Knut Hamsun is not the pantheism of Nicholas of Cusa, Giordano Bruno, or Schleiermacher, for whom the world basis of all things is a pantheistic impersonal beginning - an infinite God, manifested in all variety of objects and phenomena. Hamsun's pantheism is a kind of animism, even may be panpsychism, which consists in the belief that every living creature in nature, including trees, plants and even rocks or streams - is amazing, mysterious and beautiful, have their own spirit or divinity. In this sense, his position can be called an aesthetic-mystical pantheism, using the definition of R. Heim [21] whom characterized the work of F. Hölderlin so, or "artistic pantheism", as Dilthey put it [22].

Aesthetic perception of nature characterizes Hamsun as a romantic, for which Nature is the highest expression of beauty in the world, this is true being, and it is on nature that people's feelings are sincere and harmonious. This is especially true of the feeling of love.

In his work "Fruits of the Earth" Hamsun together with the glorification of Nature, the anthem of the earth, also glorifies the peasantry (he himself often called peasant). Peasants are not alienated from nature, from the products of their labor as workers and other layers of society. They follow nature, obeying its natural rhythm. Their work is difficult, but it is full of meaning and in harmony with natural processes. Urban and rural life for Hamsun is always antipodes. Peasant life and the eternal connection of man with the land - this is the ideal form of human existence for Hamsun, the harmonious coexistence of man and nature.

\section{REFERENCES}

[1] K. Hamsun, Pan. Collected Works. Op. in 6 vols. M., 1991., Vol.1.P.57

[2] Ibid., Vol.1, p.141

[3] The Bible. The Book of Job. Ch. 5: 7

[4] I. Kant, On the failure of all philosophical attempts at theodicy in the book. Treatises and letters. M., 1980, p.60.

[5] Galina Galina. http://www.vekperevoda.com/1855/galina.htm

[6] Declaration of an abstruse language. - Literary Manifesto. From symbolism to «October», 2001, P.193

[7] Hamsun K. Pan, p. 65.

[8] Ibid., p. 119.

[9] Ibid.

[10] Ch. by Eleonora Pankratova: Knut Hamsun - ENIGMA, mystery, mystery - Journal of Literary Review, 1992, No. 7/8/9, pp. 62-65.

[11] K. Hamsun, Pan, p. 463.

[12] K. Hamsun, Forest in the winter. Full. Coll. Op. in 5 vols. SPb., 1910., vol. 4 , p. 463 .
[13] K. Hamsun, Pan, p. 503.

[14] Hamsun' Toure. "Knut Hamsun is my father”, M.,1999, p. 203.

[15] K. Hamsun, Pan, p. 523.

[16] Ibid., p. 520.

[17] Ibid., p. 462.

[18] K. Hamsun, Victoria. Novels. Hunger. Mysteries. Pan. Victoria. Minsk. 1989, p. 53.

[19] Dante Alighieri, The Divine Comedy, Vol. 1 (Inferno) (English trans.) [1321] Translator: Courtney Langdon II http://oll.libertyfund.org/titles/alighieri-the-divine-comedy-vol-1inferno-english-trans

[20] Friedrich Schleiermacher, Speeches about religion to educated people, its despising: Monologues. M., 1911, p. 39.

[21] K. Hamsun, Victoria. Gates. M., 1996, p. 114.

[22] W. Dilthey, Das Erlebnis und die Dichtung: Lessing Goethe.Novalls. Butler, Lelplg; V., 1919. Sechste Auflage, p. 399.

[23] R. Guym, Romanticism M., 1891, p. 264. 